Natural Resources Canada, Canadian Forest Service, Science and Sustainable Development Directorate. 6 page brochure.

Tree Diseases of Eastern Canada. Canadian Forest Service. Canada Communication Group - Publishing, Ottawa, Canada K1A 0S9. Tel. (819) 956-4800, Fax. (819) 994-1498. Descriptive information on 96 tree diseases. Price in Canada $\$ 39.95$ plus shipping and handling, plus GST.

Entomopathogenic Nematodes for Insect Pest Management. 1994. D.C. Eidt and G.S. Thurston. Canadian Forest Service - Maritimes Region. M-X187E.

BOOKS FROM ST. LUCIE PRESS 100 E. Linton Blvd., Suite 403B, Delray Beach, FL 33483, U.S.A. Tel. (407) 274-9906, Fax. (407) 274-9927.

Sustainable Forestry. 1994. Chris Maser with contributions from Bernard $\mathrm{T}$. Bormann, Martha H. Brooks and A. Ross Keister. Cost US\$39.95 plus $\$ 5.95$ shipping and handling.

From the Forest to the Sea: The Ecology of Wood in Streams, Estuaries, and Oceans. 1994. James Sedell and Chris Maser. Cost US $\$ 55.00$ plus $\$ 6.95$ shipping and handling.

Ecological Integrity and the Management of Ecosystems. 1993. Edited by Stephen Woodley, George Francis and James Kay. Cost US\$59.95 plus $\$ 6.95$ shipping and handling.

Tropical Forestry. 1994. Edited by Simon Rietbergen. 328 p. Cost US $\$ 39.95$ plus $\$ 5.95$ shipping and handling.

\section{Journal Bargains for Institute Members}

The Canadian Journal of Forest Research is available to CIF/IFC members at a special price of $\$ 47.00$ per year, plus $\$ 3.29$ for Goods and Services Tax. The normal rate for individual subscribers to the journal direct from National Research Council is \$107.00. All NRC journals are available to members at greatly reduced prices. Send orders with payment to the national office.

\title{
Book Reviews / Revue de livres
}

The Challenge of Sustainable Forest Management. What Future for the World's Forests?

Food and Agriculture Organization of the United Nations, Viale delle Terme di Caracalla, 00100 Rome, Italy. 1993. 128 pp. ISBN 92-5-103370-6.

"Forest depletion in the developing world is not fundamentally rooted in logging or even in clearing for agriculture. It is rooted in poverty, underdevelopment and population growth. It is the success in confronting these challenges that will ultimately determine the fate of the greater part of the world's forests."

The Food and Agriculture Organization of the United Nations (FAO) has recently published this book which aims to increase public awareness of the issues involved in the loss and degradation of the world's forests and the consequences for humanity, and to further the implementation of sustainable forest management and of sustainable land use. The book is aimed primarily at a non-technical audience, including decision makers and the concerned general public, but will be of value to those foresters whose professional education was completed before the concept of sustainability was expanded beyond the sustained supply of timber to include all of the goods and services provided by forests.

There are eight main chapters in the book, plus a preface written by C.H. Murray, Assistant Director-General, Forestry Department, FAO, acknowledgements, an annex listing officially sanctioned and funded debt-for-nature swaps with commercial bank debt to December 1992, and a list of references. The book is based on 17 technical papers on sustainable forest management that were specially commissioned by FAO; these papers are to be published.

Individual chapters deal with sustainability in a changing world; the world's forests; the importance of forests; conflicting interests; forest management options; laws, institutions and people; international forestry; and the way ahead.

The introductory chapter discusses the evolving concept of sustainability, from the early European forestry that was concerned with the preservation of forests as wildlife reserves for hunting by kings and nobles, to the concept of managing forests for a sustainable yield of timber, to the concept of sustainability of all goods and services from the forest, ensures preservation of genetic resources and maintenance of the environment, so that the overall capacity of the forest is not diminished. But sustainable forest management must also be seen within the broader context of rural development, that conversion of forest lands to agriculture and other uses is done in a planned manner, that wastelands and degraded forests are regenerated, and that trees are integrated into the farming landscape and the promotion of agriculture. The chapter also contains an historical perspective of forest destruction, emphasizing that it has in the past occurred on a vast scale in Europe and in North America. However, as population growth rates decrease and as agricultural productivity increases, the pressures to clear forest land diminish. Thus, in North America the total forest area has stabilized, and in Europe, has increased. A similar transition is now taking place in some of the rapidly industrializing countries of the developing world. The forest area in the Republic of Korea is increasing and the economic and demographic conditions for stabilization of forests are emerging in Thailand and Malaysia.

Chapter 2 provides information on the world's forest resources and notes that about 40 per cent of the world's land surface remains under some form of forest cover. However, the estimated rate of forest depletion in the tropical zone between 1981 and 1990 was 15.4 million ha per year, significantly greater than the annual depletion rate of 11.4 million ha in the decade 1971 to 1980 . Depletion rates averaged 0.8 per cent per year, varying from 1.2 per cent in Asia, to 0.8 per cent in Latin America to 0.7 per cent in Africa. Deforestation in the tropical rain forests - the zone of most public interest - has averaged 0.6 per cent annually, while in dry and very dry zones the rate was 0.9 per cent, in the moist deciduous zone, 1.0 per cent, and in tropical upland formations, 1.1 per cent.

The fifth chapter deals with forest management options. It is noted that forests can be managed in many ways and for many purposes. The techniques used in each case will depend on the objectives, the type of forest, the available capacities and resources, 
and the local conditions and constraints. The chapter includes sections on forest management approaches in temperate and boreal forests, moist tropical forests, and dry tropical forests and discusses the conservation of genetic resources and biodiversity, trees in the landscape, agroforestry and urban forestry, forestry, forest protection and plantations.

Following sections that discuss laws, institutions and the international dimension, the book presents an agenda for action which describes programs required to ultimately lead to the sustainable, multipurpose management of natural forests and plantations, the rehabilitation of degraded forests and reforestation. Actions are grouped under five categories forestry in land use, rural development, institutional action, planning and forest conservation through management.

The book is attractive, well edited, very readable, and includes a large number of photographs. Each chapter is introduced with a full page photograph. One minor criticism is the use of scientific names in a book that is primarily written for a non-technical audience.

Any forester interested in current issues in sustainable forest management should consider the book essential reading.

$$
\text { J.H. Cayford, R.P.F }
$$

The Horse in the Forest. Caring Training, and Logging. Hans Sidback. Swedish University of Agricultural Sciences Research Information Centre/ Forestry. 112 p. 1993. \$30.00. ISBN 91-576-4762-3.

This practical little book is a very useful reference for the novice considering purchasing a horse for logging or for an experienced horse logger.

The Horse in the Forest covers things such as (1) considerations when buying a forest horse, (2) general care and training, (3) injuries and sickness, (4) economics and budgetting, (5) safety and logging equipment, and (6) planning a harvest, felling, and loading with a horse.

Simple, easy to understand language and numerous sketches and photos illustrate many basic items such as "when the horse is unsecure", "tramp injuries", "personal equipment", "loading on a slope", and "training muscle pain" to mention only a few. The completeness and breadth of this book is difficult to find in other books on the subject and I recomend it to anyone thinking of horse logging.
Originally printed in Sweden, the book has been translated to English by Joakim Hermelin of New Brunswick Dept. of Natural Resources and Energy and can be purchased from their office in Fredericton P.O. Box 6000, Fredericton, NB E3B 5H1.

Tim Whynot

Dept. of Natural Resources Halifax, NS

Compass and Gyroscope: Integrating Science and Politics for the Environment. Kai Lee, Island Press Washington DC. 243 pp., 1993. ISBN 1-55963-197-X.

This book makes a case for reasoned use of science in policy. The case examined is the conflict between hydro power and salmon population management on the Columbia River from post WWII to the present, but the application extends to renewable resource management generally. It is neither a treatise on the elegant mathematics of population management, nor is it deep reading on the philosophy and evolution of policy. Rather it is a weaving together of these two themes in a manner that makes the intricate yet powerful linkages of these two perspectives stand out. While it does not attempt to be a handbook, it should be mandatory reading for anyone who would take up a role in influencing the evolution of natural resource policy.

The book is tightly written with meaning in every sentence. Since it stresses the importance of context for resource and environmental policy decisions that made the reading, for me at least, a matter of considerable concentration. In my view the rewards for such concentration are great.

At a time when adaptive management seems to have become either an exercise in mathematics limited to those who speak that language, or alternatively, a game of flag waving that anyone can play, Lee succinctly provides a players' guide to the complex process that is real adaptive management in real natural/social systems. He does this by providing a social context for the more technical descriptions of adaptive and environmental management offered by Holling and by Walters. The book illustrates how technical adaptive management is easily derailed into academic maundering when it fails to carry the confidence of society. This little book is essential reading for anyone who would implement adaptive management in a real situation.

There are eight chapters. The first entitled "Taking measures" sets the scene by casting adaptive management - the compass - as an idealistic application of science to policy which has the singular advantage of producing reliable knowledge from unavoidable errors. He sees bounded social conflict - the gyroscope - as a pragmatic application of politics that protects the adaptive process by disciplining the conflict that comes from unavoided error. The second chapter "Sustainability on the Columbia basin" is a review of the evolution of the conflict of salmon and power. "Compass: adaptive management", the third chapter will be a reality check for many who believe that doing/saying some neat things constitutes adaptive management. Lee makes it clear that adaptive management is not a natural way for learning to occur in our society. Thus, for adaptive management to work as advertised requires major effort by both scientists and policy people in non-traditional lines of communication.

Chapter 4 "Gyroscope: negotiation and conflict" argues that shared learning is gained only with well directed effort. Chapter 5 "Sea trials: comparison cases" briefly looks at three cases and concludes on the important role of some informal organizations. Chapter 6 "Navigational lore: expectations of learning" examines how we learn about large systems and how our collective learning can be improved. In Chapter 7 "Seawworthiness: civic science" Lee argues that managing large ecosystems demands a structure for social input that he calls civic science. To me this is the crucial concept of the book. The final chapter on "Seeking sustainability" is not just an exhortation to try harder, but also to try differently.

G.L. Baskerville
Prof., Faculty of Forestry
University of British Columbia

G.L. Baskerville University of British Columbia 


\section{Instructions to Authors and Contributors / Directives aux Auteurs}

\section{General}

Contributions may be in French or in English. Double space all material intended for The Forestry Chronicle. Three copies must be submitted and will ensure the material will not get lost between editing, production and printing.

Do not use "all caps" in titles or headings. Underline only words that are to appear in italics e.g. scientific names.

Title - titles should be kept short - no more than 10 words

Author documentation - all authors' names and complete mailing address should be included at the bottom of the cover page.

\section{Scientific and Technical and Professional Articles \\ There is a charge of $\$ 100$ per page. Page charges} may be waived for papers reporting private research or for professional papers prepared privately. Requests for waiving of page charges must be made at the time the paper is submitted. The page charges include one table for each page of article. Additional tables are $\$ 11.00$ each.

Submit the original and two copies of the manuscript, typed double-spaced on white bond paper 8-1/2 $\times 11$ in. with wide margins; preferably with numbered lines. The first page should contain only the title, the authors, and footnote giving the author(s) affiliation. Footnotes should be numbered consecutively throughout the paper, except in tables. Headings and subheadings should be flush left in upper and lower case letters. References should be listed alphabetically under the heading References and referred to by the author and date, e.g. (McPherson et al. 1982) for:

McPherson, J.A., E.K. Morgenstern and B.S.P. Wang. 1982. Seed production in grafted clonal orchards at Longlac, Ontario. For. Chron. 58(1): 31-34.

(a) single-author articles preceed multiple author articles for which the individual is the senior author

(b) two or more articles by the same author(s) are listed chronologically; two or more in the same year are indicated by letters $a, b$, etc.

(c) all published works in the text should be listed; all listed references should be notated in the text.

(d) material not available through libraries (e.g., personal communication, privileged data) should be cited in the text in parenthesis.

(e) Book references must include author(s), year, title, publisher, city and number of pages (p.) (in that order).

(f) Chapter references from books must include author(s), year, chapter title, pages (pp.), In editor(s), book title, publisher and city (in that order).

(g) Articles, symposium proceedings etc. follow similar reference format.

\section{Généralités}

Les articles peuvent être présentés en anglais ou en français. Le texte est dactylographié à double interligne en respectant les marges. Le matériel soumis doit nous parvenir en trois exemplaires afin d'assurer le suivi entre l'édition, la production et l'impression. II faut utiliser dans le titre non pas uniquement les majuscules mais les hauts et les bas de case de façon normale comme dans le corps du texte. Seule les mots qui doivent apparaître en italique dans l'épreuve sont soulignés.

Titre - Les titres devraient être le plus court possible, pas plus de 10 mots.

Identification de l'auteur - Le nom de tous les auteurs ainsi que leur adresse postale complète devrait apparaître au bas de la page frontispice.

Articles scientifiques, techniques et professionnels

Des frais de publication de $100 \$$ par page sont exigibles. Ces frais peuvent être annulés advenant qu'il s'agisse d'articles falsant état de recherche indépendante, ou d'articles professionnels préparés individuellement. La requête pour l'annulation des frais doit accompagner l'article soumis. Les frais de publication comprennent la reproduction d'un tableau par page. Les tableaux supplémentaires exigeront des frais de $11 \$$ par tableau.

L'auteur soumet l'original et deux copies de son manuscrit sur feuille $8-1 / 2 \times 11$ et à lignes numérotées dans la mesure du possible. La première page contient uniquement le titre et les auteurs avec une note en bas de page sur l'appartenance de ceux-ci. Les notes en bas de page rattachées au corps du texte doivent être numérolées consécutivement dans l'article, excepté celles qui accompagnent les tableaux et les figures. Les entêtes et les sousentêtes doivent commencer à la marge avec les caractères de haut et bas de case. La liste des références suit l'ordre alphabétique et la référence dans le texte donne le nom de l'auteur et la date comme suit: pour "Robitaille L. 1977. Recherches sur les feuillus nordiques à la station forestière de Duchesnay. For. Chron. 53(1): 201-203.", on met (Robitaille 1977).

(a) les articles rédigés par un seul auteur précèdent les articles de plusieurs auteurs pour lesquels l'individu est considéré comme auteur principal

(b) deux ou plusieurs articles rédigés par le ou les mêmes auteurs sont présentés par ordre chronologique; deux ou plusieurs articles rédigés la même année sont identifiés par les lettres a, b, etc.

(c) tous les travaux publiés cités dans le texte devraient être identifiés dans les références; toutes les références citées devraient être notées dans le texte.

(d) le matériel non disponible en bibliothèque (p.e. communication personnelle, données privilégiées) devrait être cité entre parenthèses.

(e) Les références à des livres doivent inclure le ou 


\section{Submission of Manuscripts on Diskette}

Manuscripts may be submitted on 3.5- or 5.25-inch diskettes in IBM Wordperfect following acceptance. When preparing papers for submission on diskette follow the publication style as closely as possible with regard to headings, capitalization, etc. (see a recent issue of The Forestry Chronicle). Text intended to be set in italic should be underlined, text to be set in bold should be coded bold on Wordperfect; otherwise avoid superfluous word processing codes.

Some specific points:

- Use the numeral 1 (not lower case I (ell)) for the number one.

- Use the numeral 0 (not capital O) for zero.

- Do not double space after a period.

- Avoid the use of tabs and indents; be consistent in how you end and start paragraphs.

- Note any special characters used in the document.

- Send a print out of the document as it appears on the disk, not a later or earlier version.

Note: Since all corrections and editing are done on a hard copy of the manuscript, usually in red pen to be more visible to the author, diskette submissions are not needed until after acceptance, that is, after minor revisions have been completed.

\section{Tables}

Each table should appear on a separate sheet and be numbered in arabic numerals. Only the first word of the title should be capitalized, and similarly only the first word of table headings should be capitalized. Horizontal rules only are used, see The Forestry Chronicle for examples. Tables will appear as one column $(8.5 \mathrm{~cm})$, page width $(17.8 \mathrm{~cm})$ or for large tables sideways on the page $(24 \mathrm{~cm})$.

\section{Illustrations}

Line illustrations should be in black ink on white paper. Photo-reproductions of line illustrations are acceptable, but photocopies and illustrations produced on dot-matrix printers are not. When planning illustrations bear in mind that they will be reduced to fit the page or column size. All elements of the illustration should be clearly legible when reduced; lettering should be at least $1.5 \mathrm{~mm}$ high when reduced. Non-professional hand or typewritten lettering is not acceptable.

Halftone illustrations (photographs) should be clear black and white prints with good tonal contrast and sharp focus. Previously screened photographs are not acceptable.

All illustrations should be labelled with the first author's name and figure number.

\section{The Abstract}

The abstract is an abbreviated, accurate representation of the paper, of about 50-100 words, rarely longer. The abstract and up to 12 key words or phrases should appear on a separate page. The abstract should be informative. An informative abstract contains the most essential information given in the original. Results and conclusions should be given in numerical values where practical. It may indicate dates, localities, names of species, new meth- les auteurs, l'année, titre, maison d'édition, ville, nombre de pages (p.) (dans cet ordre)

(f) les références à des chapitres tirés de livres doivent inclure le ou les auteurs, le titre du chapitre, in éditeur(s), titre du livre, pages (pp.), maison d'édition et ville. (dans cet ordre)

(g) les articles, les actes de colloques, etc, suivent un format similaire de référence.

\section{Soumission de manuscrits sur disquette}

Les manuscrits peuvent être soumis en version Wordperfect de IBM sur des disquettes de 3.5 ou 5.25 pouces. Lors de l'élaboration de l'exposé à soumettre sur une disquette, veuillez suivre les normes de publication aussi fidèlement que possible en ce qui a trait aux titres, majuscules, etc. (Veuillez vous référer à une édition récente du Forestry Chronicle). Le texte qui devrait être en italique, sera souligné, le texte en caractère gras, devrait être encodé en caractère gras selon Wordperfect; en toutes autres circonstances, évitez l'utilisation superflue des codes du traitement de texte. Quelques points spécifiques:

- Utilisez le caractère numérique 1 (et non le "l" minuscule) pour imprimer le chiffre un.

- Utilisez le caractère numérique 0 (et non le "O" majuscule) pour le zéro.

- N'insérez pas de double espace après un point.

- Evitez l'utilisation de taquets de tabulation et de commande de texte en retrait, soyez consistant dans la façon de débuter et de finir les paragraphes.

- Identifiez tous les caractères spéciaux utilisés dans le document.

- Faites parvenir une copie du document tel qu'il apparaît sur la disquette et non une version antérieure ou plus récente.

N.B. Puisque toutes les corrections et l'édition sont effectuées sur une copie imprimée du manuscrit, habituellement à l'encre rouge afin d'être plus apparentes aux yeux de l'auteur, le dépôt d'une disquette n'est pas nécessaire après son approbation, du moins si les corrections mineures ont été effectuées.

\section{Les tableaux}

Tout tableau doit être présenté sur une feuille séparée et numéroté en chiffre arabe. Seul le premier mot du titre de même que le premier mot d'une case du tableau doit être affecté de la majuscule. La ligne horizontale est la seule en usage dans la revue. Le tableau doit s'accommoder soit de la largeur de la colonne (3-3/8") soit de la largeur de la page (6-5/8") ou encore du plus grand côté de la page (9-5/8").

\section{Illustrations}

Les dessins devraient être réalisés à l'encre noire sur du papier blanc. Les reproductions par procédé photographique des dessins sont acceptables, mais les photocopies et les illustrations produites par une imprimante à points ne le sont pas. Lors de la planification des illustrations, veuillez garder en mémoire qu'elles seront reproduites de façon à s'insérer sur une page ou sur une colonne. Tous les éléments des illustrations devraient 
ods etc. Information given in the title should not be repeated. The abstract should be able to stand by itself. It should not be used for second thoughts. The abstract is the most important part of a paper because it is read by the most people.

For long reviews or discussions an indicative abstract may be used. It is very short, often only a sentence which expands or clarifies the title.

Abstracts should be submitted in English and in French where possible.

\section{Spelling and Abbreviations}

The Forestry Chronicle uses the Oxford dictionary as its source for the correct spelling of words. Words such as "fertilizer" should be spelled with a " $z$ ", not an "s".

Standard metric abbreviations should be used, e.g., $\mathrm{km}, \mathrm{ha}, \mathrm{m}^{3}, \mathrm{~g}, \mathrm{~kg} \mathrm{ha}^{-1}$.

\section{Miscellaneous}

Use Native Trees of Canada for common and scientific names or Checklist of United States Trees by E.L. Little, Jr., Agriculture Handbook No. 541 for a broader list of scientific names. For technical articles the Council of Biology Editors Style Manual (fifth edition) provides useful guidelines on form and style.

Colour photographs related to articles are solicited for possible use on the cover of The Forestry Chronicle.

Submissions not complying with these instructions or not including three copies will be returned or delayed until the required changes have been made. être clairement lisibles une fois l'illustration réduite; le corps des lettres devrait être d'une hauteur d'au moins $1.5 \mathrm{~mm}$ une fois réduit. Les lettres à main levée ou à la machine à écrire ne sont pas acceptables.

Les illustrations en demi ton (photographies) devraient prendre la forme d'épreuves claires en noir et blanc ayant un haut niveau de contraste tout en étant très nettes. Des épreuves réalisées à partir d'une projection sur écran ne sont pas acceptables.

Toutes les illustrations devraient être identifiées selon le nom des auteurs et le numéro de l'illustration.

\section{Le résumé}

Le résumé est produit dans la langue de l'article et si possible dans l'autre langue reconnue par la revue. II donne en abrégé le contenu de l'article en utilisant entre 50 et 100 mots, rarement plus. Cependant, en présence d'un long article de discussion ou de revue de litérature, la résumé peut être réduit à une seule phrase qui vient uniquement clarifier le titre, il peut procéder selon l'ordre de l'article, mais il est plus efficace s'il donne d'abord les éléments les plus importants et les détails de support ensuite. II est important de se rappeler que le résumé est un document d'information important, lu par le plus grand nombre. Complet par lui-même, il donne l'essentiel de l'article: dates, lieux, noms des espèces et méthodes nouvelles de travail, il évite de répéter ce que donne déjà le titre ou d'ajouter des réflexions. Le résumé doit être présenté sur une feuille séparée accompagné des expressions et mots clés (maximum: 12).

\section{Remarques}

L'usage des noms scientifiques doit suivre la nomenclature employée dans "Les arbres indigènes du Canada" ou encore pour les noms anglais celle de "United States Trees" par E.L. Little, Jr., Agriculture Handbook, № 541. Si le nom de l'espèce n'a pas de correspondant reconnu en français et en anglais, on se limite au nom latin.

L'orthographe des mots anglais doit suivre le dictionaire Oxford pour ce qui est de l'orthographe correcte des mots, français le "Robert". En anglais "fertilizer" doit être écrit avec un " $z$ " et non un "s".

Les normes d'usage sur la forme et le style des articles techniques se retrouvent dans "The Council of Biology Editors Style Manual" (5ìme édition).

Les photos en couleurs reliées aux manuscrits sont désirées comme candidats pour le couvert de la revue.

Les articles soumis qui ne se conforment pas à ces instructions ou qui ne comprennent pas trois copies seront retournés à leurs auteurs ou seront reporté tout que les corrections n'auront pas été effectuées. 